\title{
ローレル指数の発達的変化
}

(积和 44 年: 3 月 25 月受付)

市村絪 一

\section{The Developmental Transition of Rohrer-Index.}

\section{Souichi Ichimura (Department of Psychology, Tokyo University of Education)}

Appling the estimation method of the distribution function of Rohrer-Index at each level of height by Ichimura, mean scores of R-Index at each level of height of each chronological age, from 8 to 18, male and female, were estimated. And the developmental transition of the mean score of R-Index at each level of height from eight.years old to eighty years old was considered. The followings were presented as the results.

1) During childhood and middle adolescent ages where the body development is regular the higher the estimated mean score of R-Index is at the lower height. During the preadolescent ages where the development is accelerated the estimated mean score of $R$-Index is lower at the highest and the lowest levels of height, and the highest mean score is appeared at a middle level of height.

2) Considering the mean scores of R-Index depend on the levels of height, the traditional standard of the evaluation of fatness and thinness taking (the mean of weight) + (the mean of height) ${ }^{3}$ as the standard score of a group is improper. The table of the standard score of $R-$ Index at each level of height is presented.

3) It is found that on the continuem of height there are such specific points above where the devolopment of height is more facilitated than weight and below where the development of weight is more facilitated than hight without distinction of age.

身体の充実度を示すローレル指数 $\{($ 体重 $(\mathbf{g})+$ 身長 $(\mathrm{cm})$ の 3 乗) $\times 1002\}$ は個体の発起とともに 変化するるのである，宫禹 8）や猪飼2) は各年令 の平均体重と平均身長から各年令の平均ローレル 指数：(以下 $\mathrm{R}$ 指数）を求め*，その発達的变化を 考察している，宮岛 8) によれば， R 指数は6才 (144)から16才(124) までは発達にとるない単調 に減少し，17才から20才の間に若干の增減があ る(1943 年生れの男子)。猪飼もまた同樣の倾向 があることを示している，彼によれば2，， R 指数 の極少值は 13 才ぐらいのところにある.

さて， $\mathrm{R}$ 指数はその期待值が年令によつて変化 すると同時に，同一年令の集団内においても身長

*この結果が，ある集団の $\mathrm{R}$ 指数の平均かどらかと いら証明はない，正规分布をなす二つの母集団から のサンプルの比事の分布は一般にコーシー分布をな

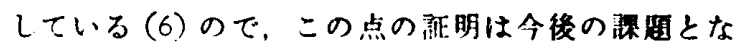
ろう.

東京教奇大”。
の大小によつていちちろしい㮅化することが水野 7）らによつて指墒されている。この身長による R 指数の期持值の变化を推定する数学的公式が市村 3により $\mathrm{R}$ 指数の COP 网数として提示された. この研究は市村の COP 网数により，各身長段 階別の R 指数の期侍值を推定し，その発䢖的推 移を考察しよらとするるのである。なお，基碤デ 一タは1959年の文部省による身長・体重の発達 の全国調查の結果を引用させていただいた。

\section{I. ロール指数の或別期待值の吐逗的推移}

同一年令の人々の冬身長段階に括ける R 指数 の期待体を推定する COP 関数は次の式で与えら れる。

$$
\mathrm{E}(\mathrm{R} \mid \mathrm{y})=\begin{gathered}
1 \\
\mathrm{y}^{3}
\end{gathered}\left\{\mu_{1}+\frac{\rho \sigma_{1}}{\sigma_{2}}\left(\mathrm{y}-\mu_{2}\right)\right\}
$$

ここで，y，的，的，はそれそれ身長，その平均 および票準偏美である， $\mu_{1} ， \sigma_{1}$ ，は体重の平均お

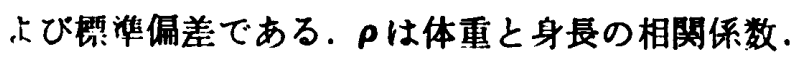


E (Rly) はある身長が与えられたとさ，その乐辰 の人々の R 指数の推定された期待値（平诗住）で ある。この公式の導き方と，この曲線の概形は文 献 (3) に示されている。

COP 閔数によつて推定される 各年令に怙ける 身畏別の $\mathrm{R}$ 指数の期待值は㸚1のと5りである. 表1飞扰いて，8～18 は男子の年令， F-8 F-18 は女子の年令, $\overrightarrow{\mathbf{x}}\left(=\mu_{1}\right)$ は各年令の平均体重, $\bar{y}(=\mu \Omega)$ は各年令の平均身畏， $r(=\rho)$ は体重と身 長の相蔺保数，(R-m) は $\frac{\bar{x}}{\mathrm{y}^{3}} \times 1002$ Kつて計 算された R 指数，m 恪身長段階に拈ける推定 される R 指数の期待值， Sはその段階における $\mathrm{R}$ 指数の散布の 1 標準偏差の值である.

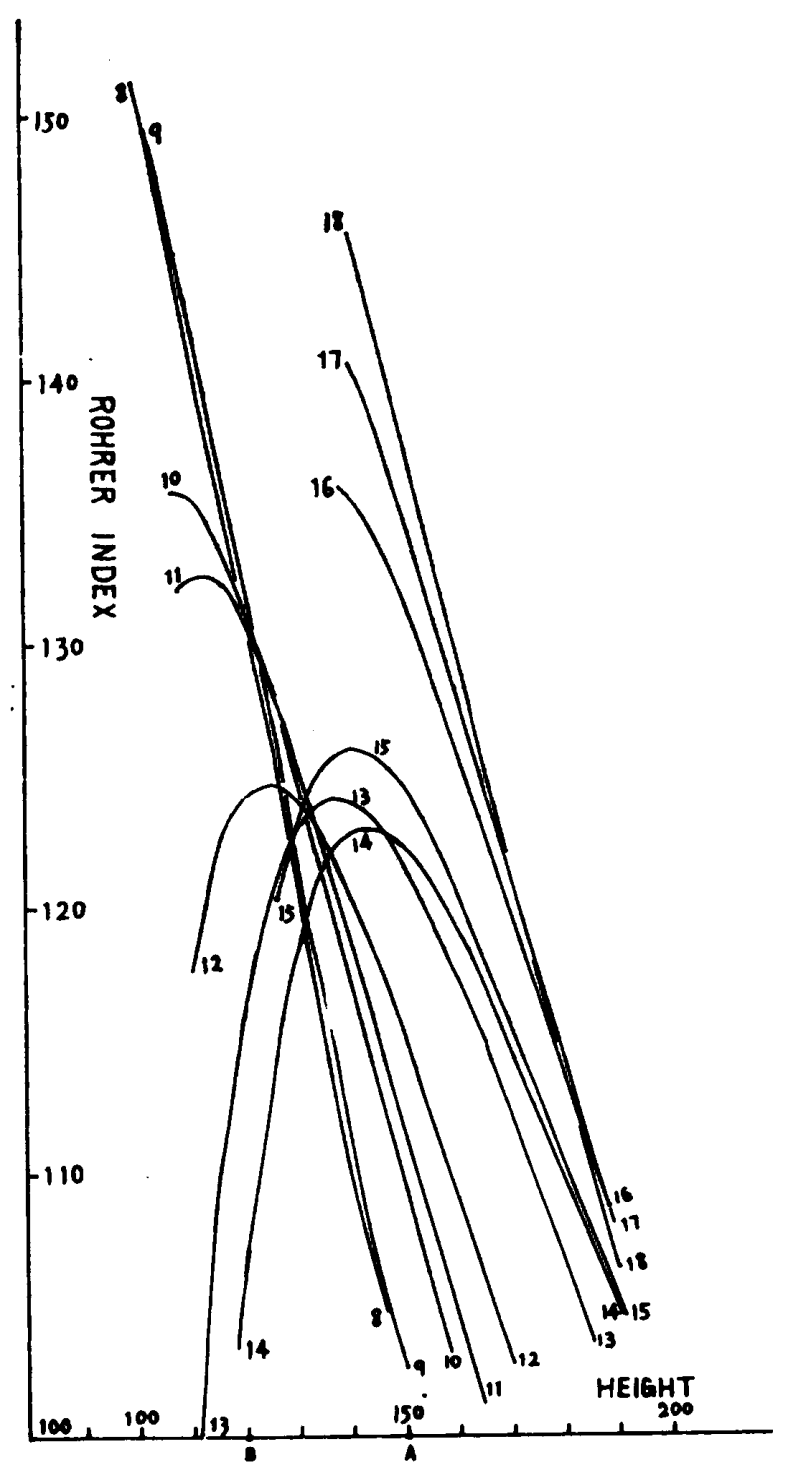

目 1 男子の身長别の平均口ーレル指数の発逞的推移 **この分布が正規分布であることの証明は文颜（3）をな照されたい。
8 才男子を例にと机は（装10第1例），平比体 面と平诗身艮から得られた従来のこの年令の標溗 的 $\mathrm{R}$ 指数数は 128.04 である。しかし，体重・身 钿がこに与克られたよらな条件で分布している 之き，各身長段陆に打计る $\mathbf{R}$ 指数の期待值は $\mathrm{m}$ の列飞示されているよらに推定（推計学的に）さ れる. 身長 $108 \mathrm{~cm}$ の人々の $\mathrm{R}$ 指数は期待值が 144.1，標临偏差か331.2の正規分布**をなす。 $123 \mathrm{~cm}$ の人々に扰いては R 指数の期待値は 128.2 であり，138cm の人々においては112.4である。

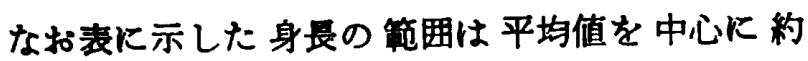

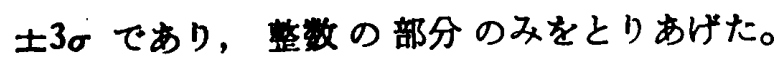
COP 关数は整数部分だけでなく，有理数の籁囲で
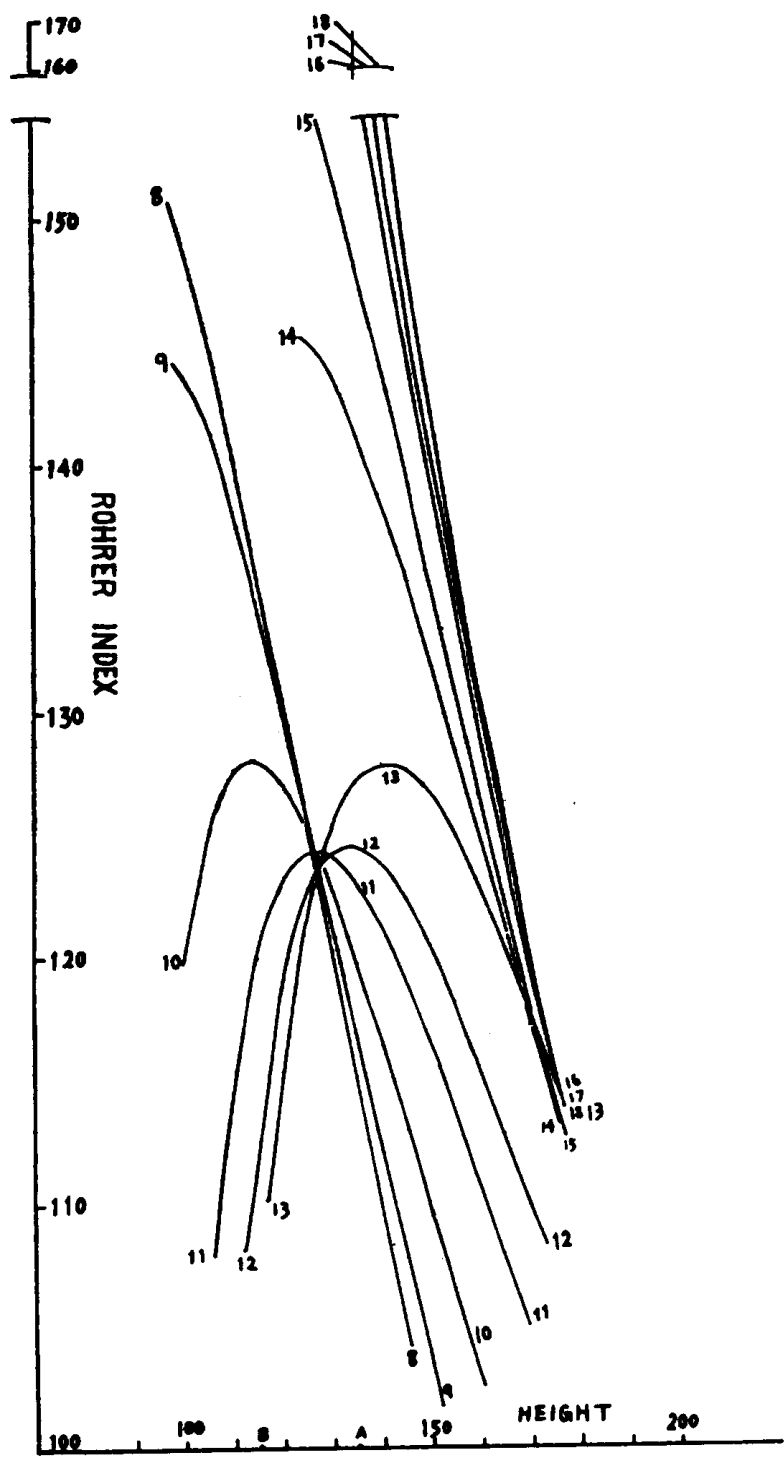

因 2 女子の身長別の平均ローレル指数の無達的推移 


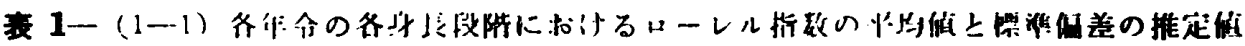

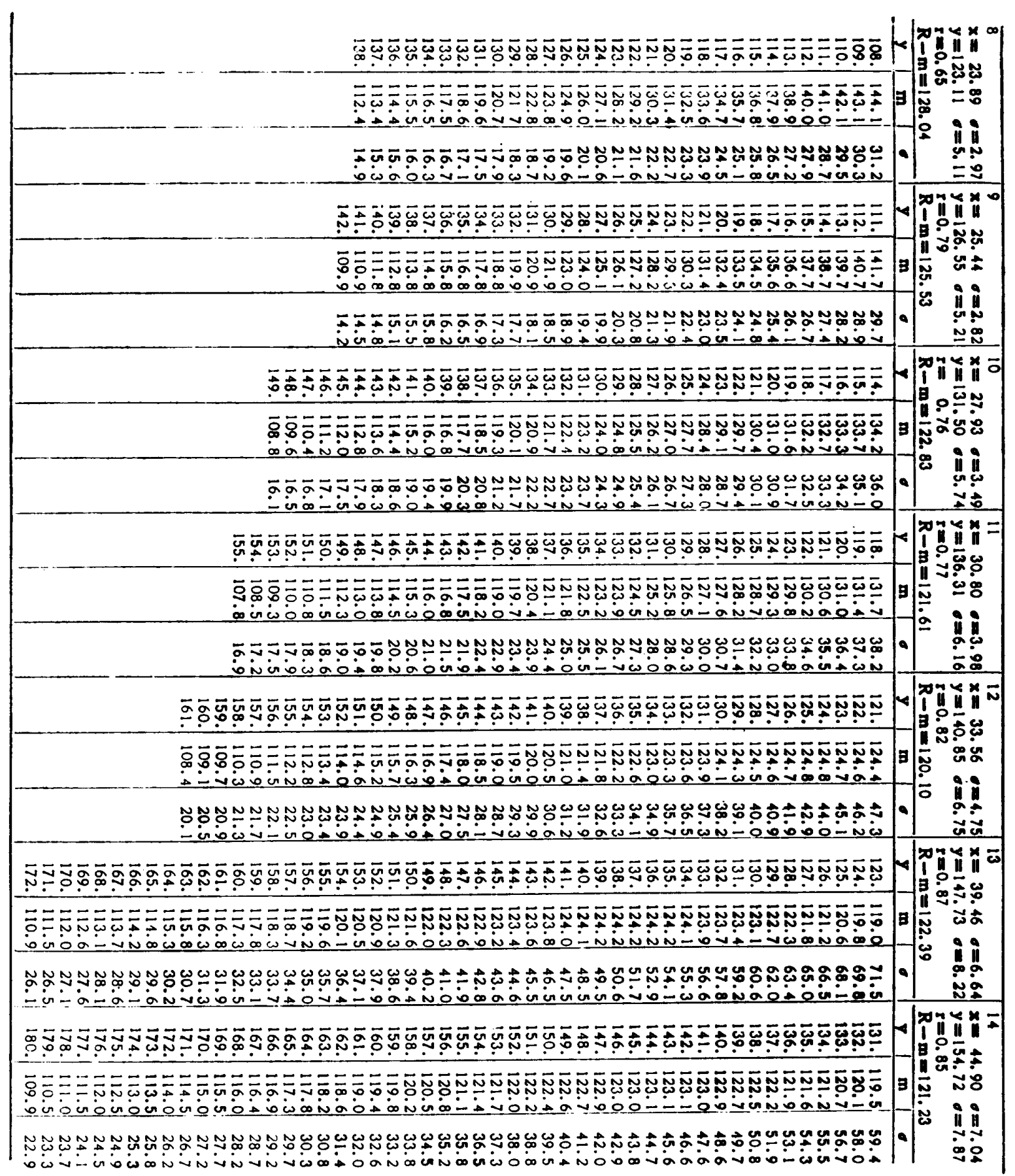


12

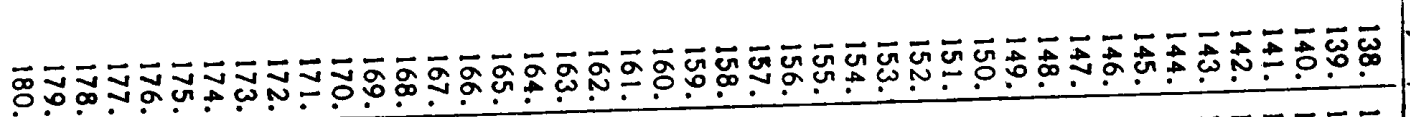

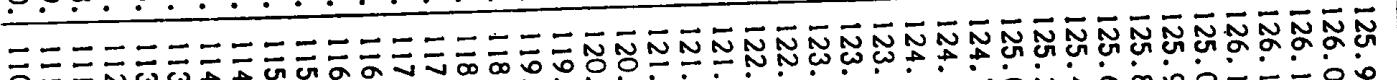
- N Ф๐.

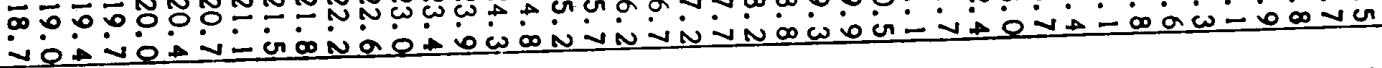

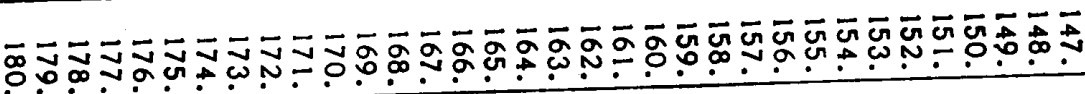

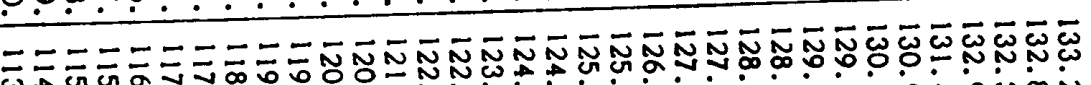

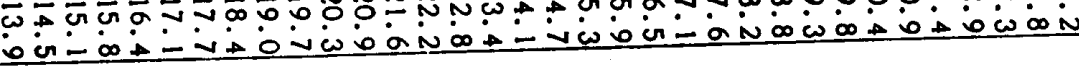

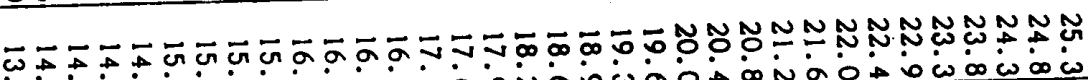

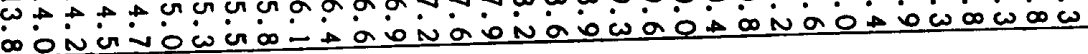

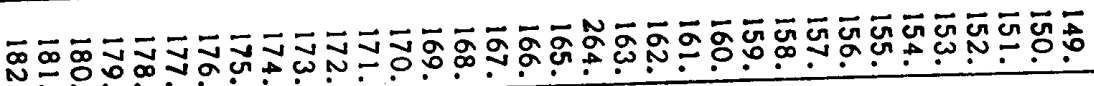

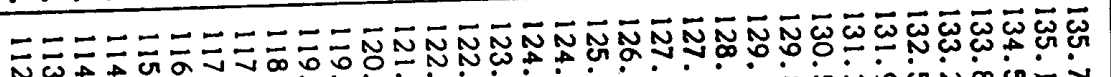
Nop

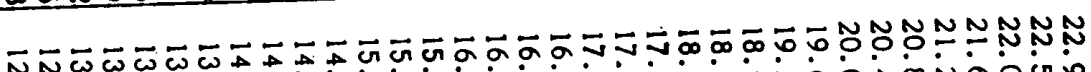

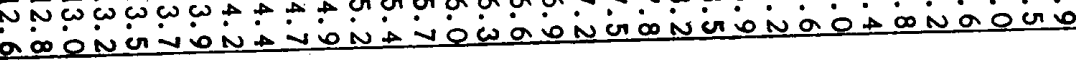

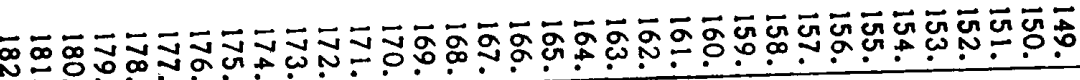

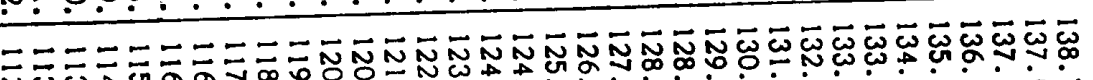

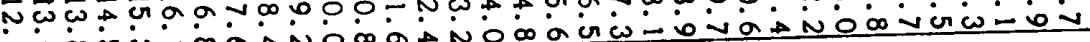

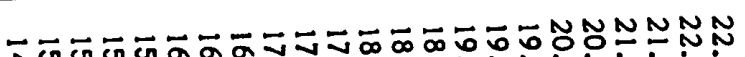

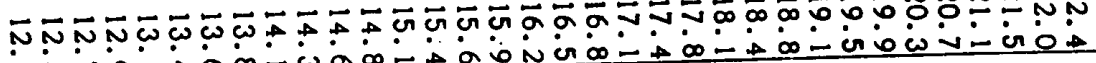

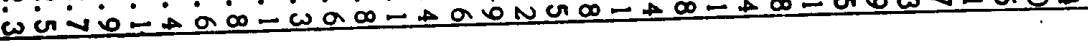

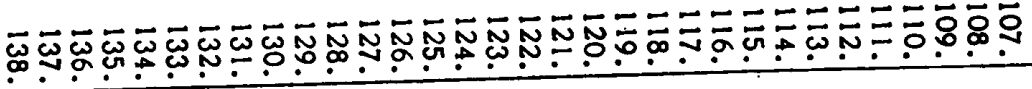

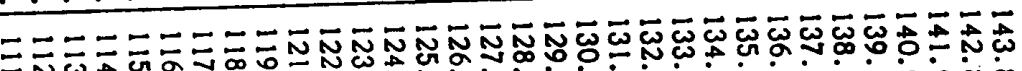
作

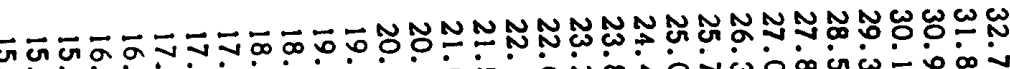
Na

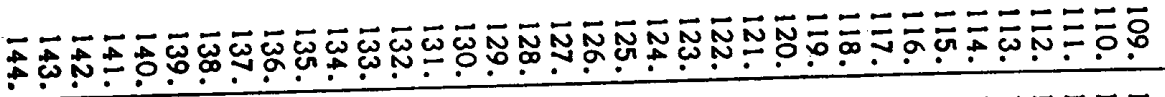

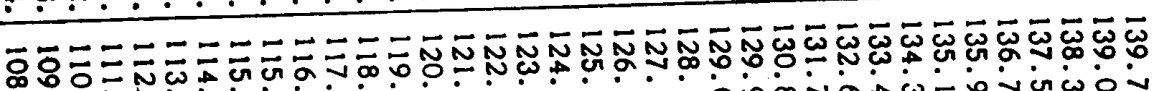

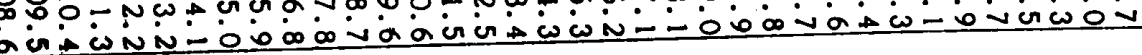

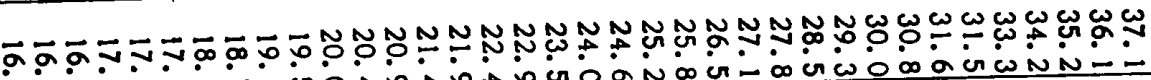
DNUDCU Un

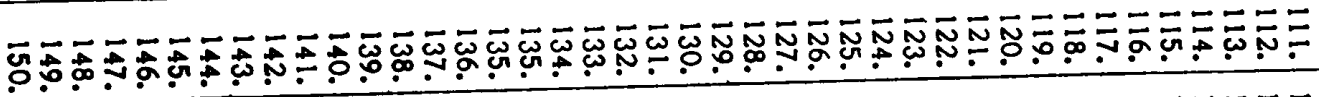

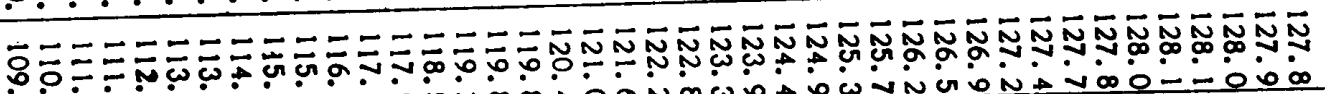

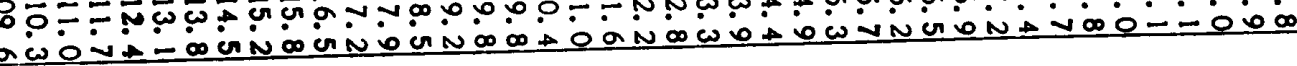

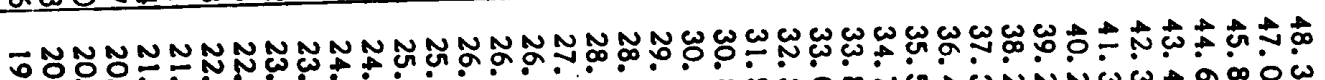

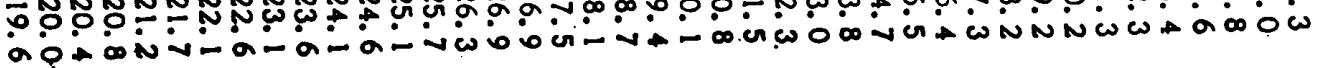

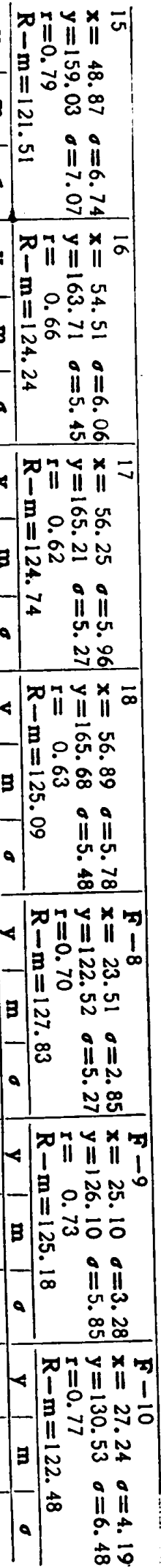


㷧 13

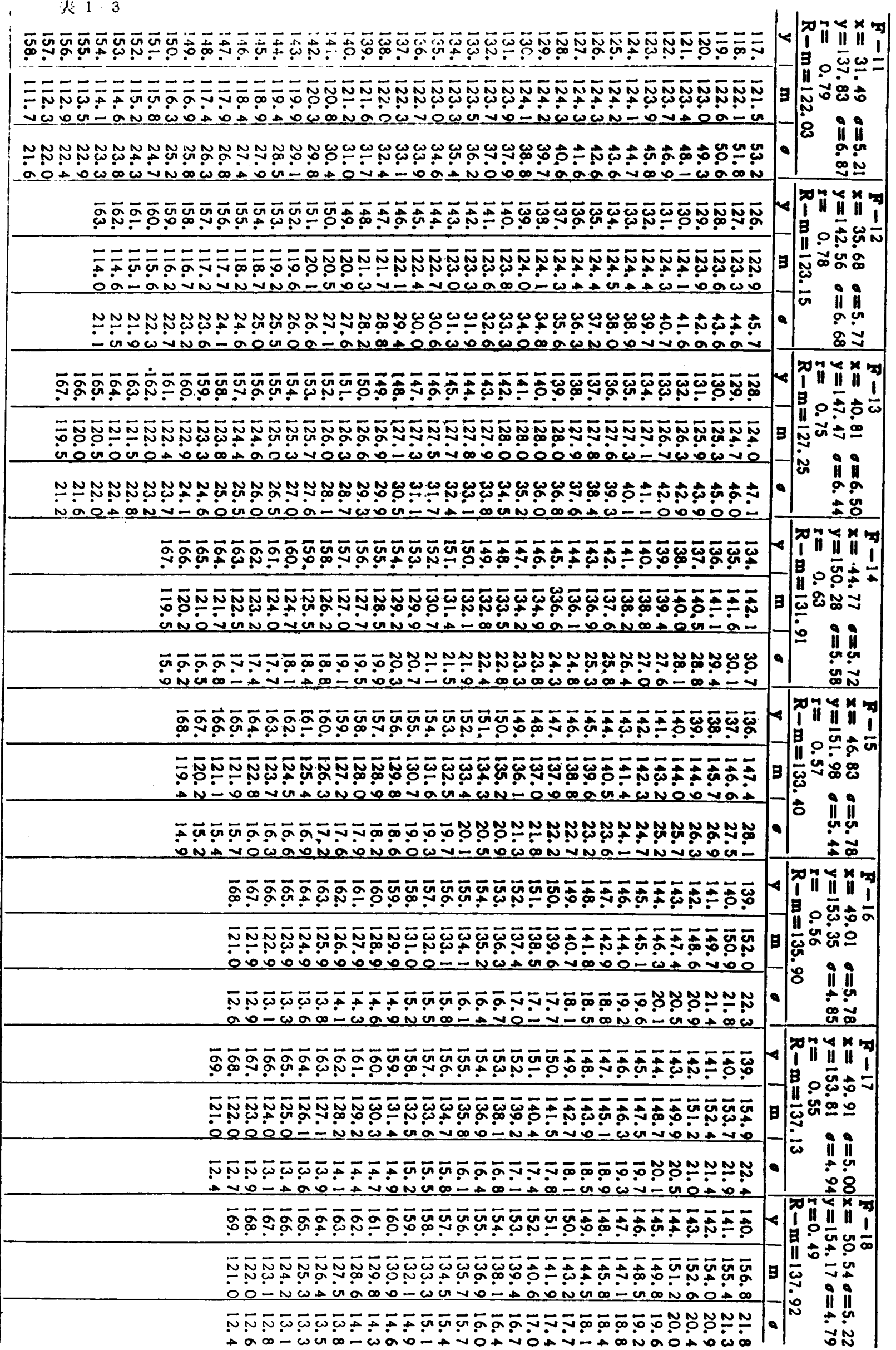


推定が形能である（例，身長 $125.3 \mathrm{~cm}$ の人の $\mathrm{R}$ 指数の期待值など).

表 1 に示された結果を発達的に考察するため に，COP 网数の推移を男女別にそれそれ图 1，図 2に示した。ここでは推移の過程を詳しく調べる ために，身舆の範囲は平均を中心に $\pm 4 \sigma$ がとら れている，横軸に身長がとられ，樅軸にR指数の 期特值の推定值（E (R/y)）がとられている. 曲 線の両端に記入された数字は年令を示している。

\section{* 家}

因1，図2に示された結果をみると各身畏段階 において R 指数の期特值はかなりの差異がある。 児童期と青年中期に括いては，身畏の低いるのの $\mathbf{R}$ 指数の期待值は高いるののそれより高くなつて いる.また他の年令においてる，各身長段階の $\mathrm{R}$ 指数が一定であることはない。このことは，従来 $\frac{\mathrm{x}}{\mathrm{y}^{3}} \times 1002$ をある年令の標策的 $\mathrm{R}$ 指数として各 调体の肥满やャセの程度を評価していた方法の適 切さえの聚間を生じさせるるのである。8才の男 子を例にとれば， $110 \mathrm{~cm}$ の人の平均 $\mathbf{R}$ 指数は $130 \mathrm{~cm}$ の人のそれよりる大であり，身長を1边と ナる正立方体の中にしめる体組轼の割合が身長の 低い人のはうが大であると玮定することはでき る.しかし，その湖定結果をるつてただちに，身 長の低い人は肥满していると評価することはでき ないであろ5。 R 指数の各身長段階における散布 の状態を考虑に入れて評価の問題を考えてみよ $5.134 \mathrm{~cm}$ の人の平均 $\mathrm{R}$ 指数は116.5 であり， $1 \sigma$ は16.3である. 平均から肥つた方に $1 \sigma$ 離れ た值は $132.8 て ゙ あ り ，$ 正規分布であるから，134cm の人で 132.8 より大きい $\mathrm{R}$ 指数の值をとる人は $134 \mathrm{~cm}$ の人全体の $15.87 \%$ にす巳゙ない。しかし 132.8 は $119 \mathrm{~cm}$ の人の標準的 $\mathrm{R}$ 指数 132.5 とほ とんど同じである. $134 \mathrm{~cm} て ゙ R$ 指数 133 はやや 肥满であるが $119 \mathrm{~cm}$ の人では漂準的であると評 価されるべきであろら。この原理を一般化すれ ば, 各身長段階の R 指数の推定平均値からのず れの程度によつて㳙满とヤ七の評価は行なわれる べきであろ5。このことは，身長を1辺とする正 立方体の中にしめる体組織の密度の测度としての
$\mathrm{R}$ 指数の有必性を页定するるのではない。

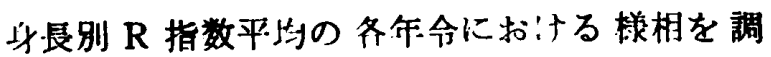
ヘていくと戍1，2，に示さ机ているように，1つ のシステイマテックな推移がみられる.

男子の場合8才から11才までの COP 曲線は 身長の增大とともに娍少している。これと同じ頓 向は 16 才から18才までの COP 曲線にす見出せ る. その中間の 12〜15才に扣いては山形の曲線 である。この3つの型を類型化して描くと因 3 の よらになる。

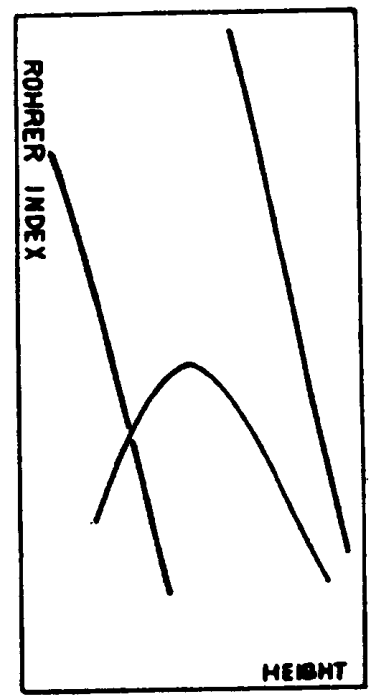

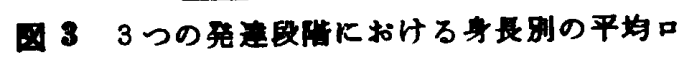
ーレル指数の形

図3のパターンは山に銀问が䍐つたよらなるの あある．上武は5）青少年の 身体発達の特徽的な 3つの時期を（1）12・3才頃の思春期勃発までの 比交的定常的な発育の時期，(2) それ以後 $15 \cdot 6$ 才頃までの急激な発育の時期，(3) ほほ220才頃 までの瑷僈な発育の時期と分けている．困3の銀 河の左の線のタイブは上武の（1）に，山形の部 分は (2) に, 銀河の右の線は（3）に相当してい るよらにみ光る．定常的な発達を，ここでは発達 曲線に大きな加速度がみられない状態と考えてお こ5．坚童期と青年中期との定常的な身長発遗の 段階では身長の低いるのの注 5 か $\mathbf{R}$ 指数の期待 值が高くなつている.なお，この2つの時期の違 いは，児童期では $\mathrm{R}$ 指数が身長の低いるのでは 小さくなつていく蛽向をみせるか，青年中期では $\mathrm{R}$ 指数が大になつていく傾向をみせている.一方 青年前期では COP 関数は山形となり，身長の低 


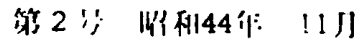

いものの R 指数平的が洏いものと同じように小 さくなつている。このことは，身体の加速们発進 の時期に身長の低沫つたものは，体重よりまず光 長の発涚が行なわ机ていくことを示しているよう である.この山形の曲線が出現する時期は男女に よつて差がある、戍2に示されているように，女 子の場合 10 才で山形の曲線が現われる，一方男 子は12才である.そして14才ではすでに，青年 中期の特街である単調減少の形を示している。

COP 関数の考察として，む51つの事実を示

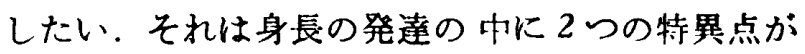
存在していることである。

男子の $150 \mathrm{~cm}$ とい5点を注目していただきた い. 10 才での R 指数平均は $106.0 ， 11$ 才-111.5, 12 才 -115.2 , 13 才 $121.6 ， \cdots \cdots 17$ 才 -135.1 ， 18 才ー137.9である，このよ5に $150 \mathrm{~cm}$ におい ては年令の增加にともなつて 1 つの例外むなく $\mathbf{R}$ 指数の平均值は增大していく。このことは，10才 で $150 \mathrm{~cm}$ といらのはきわめてをれであるにせよ， この点に達したものは時間の終過とともに R指数 が增大していく，身長の伸長期があつたとしても それは加速的ではなく，つね体組䅧の充実が優 つている発達過程といらべきであろう．このよう な傾向は $150 \mathrm{~cm}$ 以上の場合まつたくあてはまる のである，このよらな傾向のはじまる最低身長を 身体発達の特異点 $\mathrm{A}$ とする，女子の場合この特鲯 点 Aは $135 \mathrm{~cm}$ 近辺にある。

も5一つの特異点は, 年令の経過ととるに R指 数平均が小さくなる身長の点である，男子の場合 $120 \mathrm{~cm}$ に打いては R 指数平均が，8才一131.4, 9 才 $-132.4,10$ 才 $131.0,11$ 才ー131.0，12才 $-124.2,13$ 才 $-116.0,14$ 才ー107.4, とシステ イマテイックに滅少している。この点に扗いて は，身長の発達と体重の発達を $\mathbf{R}$ 指数の考光方 からみれば，体重の発澾より，まず身長の発達に 重点が植かれていると考学るべきであろう．この 点を身体発達の特異点 B とする. 女子の场合こ の特異点 B は $115 \mathrm{~cm}$ の近辺に見出すことができ る.

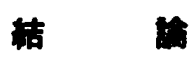

1959 年文部省の身体・体禹の全国洞查のデータ
をもとに，8才から18才までの男女の备年令にお ける冬身長段階の口ーレル指数の期特值の 推定が 行なわれた. その結果の発幸心理学的な 考察によ り次の結論が得られた。

1）定常的な身体発達を示す児童期・青年中期 においては，身長の 低いるのの R 指数の 期待值 は身長の高いるののそれよりも大である，青年前 期においては身镸の低い方と高い方の雨端飞向つ て $\mathbf{R}$ 指教の期待值は小さくなり，その中間飞最 大値がある。

2） $\mathrm{R}$ 指数の各身長段陵における期待值はかな りの差があるので，肥满・ヤ七の䛨価をする場合 は期待值からの卧を基筆としなければならない ことが示唆された。

3）年令にかかわりなく，ある身長段陵に 達す るまでは体重に比して身長の発连が侵先的に促進 され．ある段階に達すると体重の発達に重点が置 れるよらな特異点が身長の中に 存在することが想 定された，

この研究では，東京数育大学松田岩男助数报，計

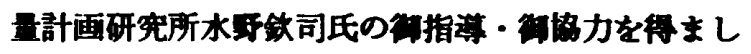

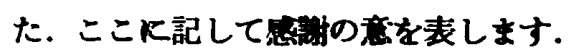

\section{考文 新}

1) Fisz, M.: Probability theory and mathematical Statist:c, Wiley, 1963.

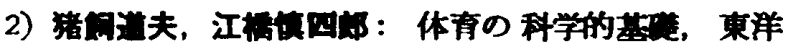
館出版, 1968.

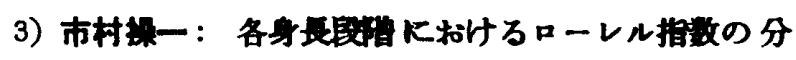
布の推定法，体有学研究，Vol. 14, 1, 44〜 51, 1969.

4) Ichimura, S: Probability distribution functions of accomplishment scores, Bulletin of The Faculty of Education, Tokyo Univensity of Education, vol. 15, 67〜72, 1969.

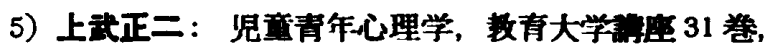
金子衰房, 1959.

6) Kemeny, J.G. et al.: Finite mathematical structures, Prentice-Hall, 1959.

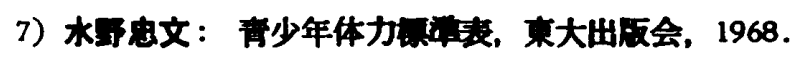

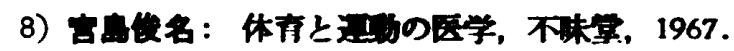

